\title{
Global Innovation Trends and Georgia
}

\author{
Shota Shaburishvili \\ Ivane Javakhoshvili Tbilisi State University \\ Maia Chania \\ Sokhumi State University
}

\begin{abstract}
Continuous and progressive technological changes based on scientific-technical revolution have become common under modern globalization processes. They gradually destroy the traditional distinction between low and high-tech sectors and shift the general vector of development of the country from static, temporary comparative advantages to innovation-based dynamic competitive advantage. In other words, innovation is becoming a significant resource that determines a competitive advantage of a country and is essential for achieving efficient and rapid improvement of welfare of a society. What is business innovation? How does innovationinfluence business development and its management in the country? In modern global business management success can't be achieved without application and proper management of up-to-date technologies. As a result, in recent years, scientists have paid special interest to the importance of technology and scientific and technological progress in business development.
\end{abstract}

Keywords: Innovation; Science; Technology; Research; development; Competitive Advantage

\section{Introduction}

\section{Understanding the Concept of Business Innovations}

The impact of innovationson business processes and final outcomes of production is one of the pressing issues in economic development. In modern global business management success can't be achieved without application and proper management of up-to-date technologies. As a result, in recent years, scientists pay special interest to the importance of technology and scientific and technological progress in economic development. In our opinion, this is caused by the global e-commerce boom beginning in the 1990s and the idea dominating in current economic thinking that scientific and technological advancement increase in productivity is one of the key factors in improving competitiveness of a company and welfare of a society.

One could find many definitions of innovations in the modern economic literature. Innovation is technological, technical and managerial novelty based on scientific advances and experience, as well as the latest and materialized idea recognized in the market. In a broader sense it is the outcome of ideas, experiments and research transformation, new or improved researched or social - economic results designed for practical use. The essential characteristic of innovation is novelty, ability to satisfy market demand and commercial viability (Strovsky, 2007).

From the novelty viewpoint, innovations include:

- New or improved goods;

- New or improved technological process;

- New forms of managing production, trade, financial or any other activities.

From market demand satisfaction viewpoint, innovation can be:

- Evolutionary. It manifests itself in modification of an existing product and is created in response to the familiar market needs. However, it is considered to be the best way of satisfying demand 
- Revolutionary, directed to satisfying demand, originated simultaneously with novelty. Innovations of this kind are rarely and unexpectedly born. Actually, they create a new market.

Comparison of revenues and costs is the basic criterion of realization of any new idea(Shaburishvili, 2013). Technical novelty cannot be regarded as innovation unless it brings an economic effect in terms of profit, reduction of production costs, improvement in productivity, etc.

\section{The main Components of a country's innovative potential}

In the age of globalization the fate and future of a country and its competitiveness in the market depends on its ability to be included into the new innovation contours of the world economy. Besides production of scientific knowledge and technological know-how, it increasingly depends on variables that describe innovative potential of the country, such as:

$\checkmark$ Research and development: innovation processes are characterized by a significant increase in the role of science. Currently, research and development represent not only a source of new ideas, but also a resource that covers all stages of the innovation process. Naturally, a starting point for assessing this variable is expenditures on R\&D, which can be divided according to sources of funding, branches of science, types of business activities and socio-economic objectives;

$\checkmark$ Innovations in enterprises: introduction of technological innovations is actively applied by modern enterprises to achieve and maintain competitiveness; therefore, this variable includes expenditures of enterprises on innovations throughout the country, as well as technological aspects of the enterprise culture, such as: innovation priorities; experience in introducing innovations; a competitive position in domestic and international markets; level of interest in strategic partnership with innovators, etc;

$\checkmark$ High-tech manufacturing and the knowledge-based service sector: innovative potentialof the country depends on the development of high-tech and knowledge-based industries in the country and their role in sectoral composition of economy, which can be evaluated in the context of economic, employment and scientific research indicators(Meskhia \& Shaburishvili, 2015);

$\checkmark$ Intellectual property: patents, copyrights, trademarks, professional secrets are the most common methods of intellectual property protection. The countries that cannot ensure protection of property rights on intangible assets lose the possibility of formation of intellectual assets. In addition, patents reflect the outcomes of activities in the field of inventions in the country. The number of patents in the country also shows its possibility of application and commercialization of scientific innovations. In this context, the patent statistics directly reflects the country's innovative potential;

$\checkmark$ Human resources in science and technology: innovative potential of the country is essentially determined by the number of people employed in scientific and technological fields in a certain period. In assessing these variables the following aspects can be observed: human resources in science and technology by gender, age, education, business area. Human resources with the third level of education in science and technology and their international mobility are essential components of this field;

$\checkmark$ Information society indicators: frequency of usage of innovations and communication technologies in households and enterprises directly indicates the level of technological environment development. As a rule, indicators of information society include usage of information and telecommunication technologies, internet and other electronic networks; level of ecommerce and business development; investments in and expenditures on information and communication technologies; security of information and communication technologies(Gogodze, 2010).

$\checkmark$ Cooperation between entrepreneurial and scientific sectors: under global competition, technological dynamism of a country is closely connected to the development of various forms of partnership between private and scientific sectors. Forms of such cooperation include development of scientific and technological parks, innovation centers, joint research projects, university research and technology centers, agreements on industrial and university research, scientific and research consortia, etc. As a rule, powerful scientific and industrial complexes are university-based. Silicon Valley in the US, based at Stanford University, is one of the best examples of global technological revolution and such complexes.

$\checkmark$ Stimulating role of the state: in the modern world, innovative development of the country depends not only on the above factors but also on the effectiveness of the state policy from the point of supporting innovative activities. The more active and effective measures are taken by the government the more attractive is the technological environment of the 
country. In this context, the following areas are very interesting: Structural policy, which includes government initiatives in various areas - technological and competition policy, deregulation, reduction of tax burden, encouraging hi-tech foreign investments, participation in major research projects, preferential loans to innovative business, free or preferential transfer of land or state property to innovative enterprises and scientific infrastructure organizations, etc.; Intermediary policy the state takes the responsibility to organize meetings of scientific and business representatives with governmental structures; such meetings should encourage development of partnership and strategic cooperation between the parties; The policy of a demanding consumer - the state sets high standards on the quality of goods and services, technology and the manufacturing process, thus making companies design and implement innovations(Meskhia \& Shaburishvili, 2015).

$\checkmark$ Internationalization of research: the generation of scientific knowledge and technological "know-how" depends more and more on the research carried out in the frames of joint projects implemented in several countries. The participation of a country in internationalization processes is affected by the following factors: the size of a country (as a rule, scientific and technological area of small countries is more internationalized); geographical proximity to the regions, which are actively involved in research activities; industrial specialization; the nature of business activities of branches and subsidiaries of foreign firms, etc(Strovsky, 2007).

\section{Formation of a company's new technological foundation}

Since 2001 European Commission has been conducting the research Innobarometer, which aims at studying the role of innovations in the European Business. The results of the last one published in 2015 look as follows:

> Almost three quarters of EU companies have introduced innovations since January $2012(72 \%)$ - an increase of six percentage points since the last survey in 2014. More than four in ten (45\%) have introduced new or significantly improved services, $42 \%$ new or significantly improved goods, $38 \%$ new or significantly improved organizational methods, $36 \%$ new or improved marketing strategies and $32 \%$ new or significantly improved processes.

$>$ For most companies, innovative goods or services accounted for up to one quarterof turnover in 2014 (63\%), while $18 \%$ say these innovations accounted for over one quarter of turnover.

$>$ More than one in five companies (22\%) have invested more than $5 \%$ of turnover on the acquisition of machines, equipment, software or licenses.

$>$ Companies investing in innovation are most likely to have invested in machines, equipment, software or licenses $(70 \%)$, in training $(64 \%)$, in company reputation and branding $(59 \%)$ and in organization or business process improvements $(53 \%)$ (Innobarometer, 2015).

The accepted wisdom is that innovators entirely depend on "good luck" in their innovative activities, because the chances of complete loss and huge success are almost equal while implementing innovations. The economists $\mathrm{W}$. Chan Kim and Renee Mauborgne have studied the problem for ten years and explored 200 innovation implementation cases (Kim \& Mauborgne, 2000). In their work "Profitable Business Idea" they distinguish 4 essential economic prerequisites of commercially viable business idea. These prerequisites are integrated into "commercially viable business idea" index, which can be applied by innovators:

1. Benefit: whether new goods and services attract consumers;

2. Strategic calculation of prices: What price strategy is applied by a firm in order to attract mass consumer?

3. Business model: How profitably can a firm realize new idea? Are the innovators capable to accomplish certain tasks?

4. Determining the possibility of expected difficulties.

We can distinguish three main stages in innovators' foreign economic activities:

At the first stage, companies export final products. That is the export of technological and other novelties in an indirect way. Naturally, science intensive export requires huge investments in research and development. Despite this, it is regarded as the most profitable activity. Besides the company's competitiveness, science and technological potential of the home country, labor skills, employment and national income as a whole increase.

At the second stage, companies start producing innovative products via FDI. It enables innovators to save transport costs, use cheap foreign labor and materials and seize a new segment of the foreign market. It is useful for the recipient, too, because FDI is an additional source of income, which helps to accelerate technological progress of a country. 
At the third stage, technologies are sold abroad. As a rule, technology does not have a special innovative value for the exporter any more, although there are segments of the world market, where it can bring some profit. For example, those technologies which are already obsolete in developed countries, may have considerable value from the novelty viewpoint and be commercially viable abroad(Daniels, Radenbaugh, \& Sullivan, 2013)

Firms operating in high technology sectors attach particular importance to the time needed to adapt consumer with the novelty. According to this parameter, the following segments can be distinguished:

1. Innovators (about $2,5 \%$ of the market) are ready to take risk and try goods first. Although their number is moderately small, they manage to persuade more passive consumers;

2. Early followers $(13,5 \%)$ are first to imitate innovators and play the role of leaders, whose view is important for adaptation to new product markets;

3. Early majority (34\%) are very careful to purchase new products and don't often take leaders' positions.

4. Late majority (34\%) are skeptical about innovations and adapt novelties only under certain economic and social conditions(Doyle, 2002).

When exporting innovative products companies should be focused on the first two segments, which are small in number, but make an important influence on formation of consumer attitude towards the novelty. Positioning, pricing, distribution and stimulation strategies should respond to the peculiarities of the very market segments.

\section{Features of Innovative Development in Georgia}

Unfortunately, Georgia's export and economy structure in which dominated agricultural products, raw materials (gold, copper), etc., makes draw two unfavorable conclusions (Meskhia \& Shaburishvili, 2014):

1. Innovative activities of Georgian firms are low. That impedes to reach and maintain international competitiveness;

2. The Georgian model of economic development does not correspond with and is not even similar to that of developed countries. Georgia does not hold not even a single niche in the world market of innovative products.

Despite this, shift to the innovative model of development is of vital importance. Rivalry of Georgian firms with the firms of developed and some developing countries has no prospects.

Table 1. Some innovative development parameters of EU and Georgia

\begin{tabular}{|c|c|c|c|c|c|}
\hline & $2014^{*}$ & $2014^{*}$ & $2014^{*}$ & $2015^{\star \star}$ & $2015-16^{* * *}$ \\
\hline countries & $\begin{array}{l}\text { Human } \\
\text { Development } \\
\text { Index } \\
\text { (HDI)Rating for } \\
188 \text { countries }\end{array}$ & $\begin{array}{l}\text { R\&D costs, in \% } \\
\text { from GDP } \\
2005-2012\end{array}$ & $\begin{array}{l}\text { GDP per } \\
\text { capita\$ (from } \\
2011 \text { ) }\end{array}$ & $\begin{array}{l}\text { Global } \\
\text { Innovation Index } \\
\text { (GII) -Rating for } \\
141 \text { countries }\end{array}$ & $\begin{array}{l}\text { Global } \\
\text { Competitiveness } \\
\text { Index } \\
\text { (GCl)Rating for } \\
140 \text { countries }\end{array}$ \\
\hline Austria & 23 & 2.8 & 44,376 & 18 & 23 \\
\hline Belgium & 21 & 2.2 & 40,607 & 25 & 19 \\
\hline Bulgaria & 59 & 0.6 & 15,695 & 39 & 54 \\
\hline Germany & 6 & 2.9 & 43,207 & 12 & 4 \\
\hline UN. Kingdom & 14 & 1.7 & 37,017 & 2 & 10 \\
\hline Denmark & 4 & 3.0 & 41,991 & 10 & 12 \\
\hline Spain & 26 & 1.3 & 31,596 & 27 & 33 \\
\hline Estonia & 30 & 2.2 & 25,132 & 23 & 30 \\
\hline Ireland & 6 & 1.7 & 44,931 & 8 & 24 \\
\hline Italy & 27 & 1.3 & 34,167 & 31 & 43 \\
\hline Cyprus & 32 & 0.5 & 27,394 & 34 & 65 \\
\hline Latvia & 46 & 0.7 & 21,825 & 33 & 44 \\
\hline Lithuania & 37 & 0.9 & 24,483 & 38 & 36 \\
\hline Luxembourg & 19 & 1.4 & 87,737 & 9 & 20 \\
\hline Malta & 37 & 0.8 & 28,828 & 26 & 48 \\
\hline Netherlands & 4 & 2.2 & 44,945 & 4 & 5 \\
\hline Poland & 36 & 0.9 & 22,877 & 46 & 41 \\
\hline Portugal & 43 & 1.5 & 25,596 & 30 & 38 \\
\hline
\end{tabular}




\begin{tabular}{|l|l|l|l|l|l|l|}
\hline & Romania & 52 & 0.5 & 18,200 & 54 & 53 \\
\hline & Greece & 29 & 0.7 & 24,540 & 45 & 81 \\
\hline & France & 22 & 2.3 & 37,154 & 21 & 22 \\
\hline & Slovakia & 35 & 0.8 & 26,263 & 36 & 67 \\
\hline & Slovenia & 25 & 2.8 & 27,576 & 28 & 59 \\
\hline & Hungary & 1.3 & 22,914 & 35 & 63 \\
\hline & Finland & 24 & 3.5 & 38,846 & 6 & 8 \\
\hline & Sweden & 14 & 3.4 & 43,741 & 3 & 9 \\
\hline & Czechia & 1.9 & 27,959 & 24 & 31 \\
\hline & Croatia & 47 & 0.8 & 20,063 & 40 & 77 \\
\hline & Georgia & 0.2 & 6,946 & 73 & 66 \\
\hline
\end{tabular}

${ }^{*}$ The Human Capital Report 2015. World Economic Forum. http://www3.weforum.org/docs/WEF_Human_Capital_Report_2015.pdf

** The Global Innovation Index 2015. Effective Innovation Policies for Development. Cornell University, INSEAD, and WIPO,

2015http://www.wipo.int/edocs/pubdocs/en/wipo_gii_2015.pdf

***The Global Competitiveness Report. 2015-2016.World Economic Forum. Geneva,

Switzerlandhttp://www3.weforum.org/docs/gcr/2015-2016/Global_Competitiveness_Report_2015-2016.pdf

Georgia is rich in intellectual capital. Accordingly, Georgia possesses the most significant resource for economic development, and its rational use will provide considerable growth. It is necessary to realize that the long-term development vector of the country must be determined by human capital. Georgia needs national policy which will lead to formation of a powerful innovative sector. Our country will be able to take its worthy position in global division of labor by means of the very sector.

Georgia has considerable advantages and opportunities to shift the new model of development:

- Universal secondary education system;

- Developed (reformed) higher education system;

- A large network of research institutions;

- Internationally recognized scientists;

- Cheap and high skilled labor;

- Liberal trade regime;

- Favorable investment climate;

- Opportunities of formation of free industrial zones;

- Democratic political system;

- Favorable geographical location;

- Membership in international organizations;

- Participation in international projects.

The main weaknesses and threats for Georgia's innovative development are:

- Low technological level of production facilities;

- Lack of financial resources for modernization and renovations;

- Low quality of management;

- Imperfect institutional and legal mechanisms for stimulation of innovative activities;

- Deformation of industrial structure;

- Weak orientation on quality improvement;

- Threat of political instability, lost territories.

The experience of some developed and developing countries (China, India, Vietnam, countries of Central and Eastern Europe) shows that attraction of FDI accelerates innovative processes. Production system modernization by means of foreign resources has enabled these countries to reach foreign markets and take certain niches there. Entry of transnational corporations encourages innovative development: subsidiaries are established not only to produce goods and services, but also have a research function. There has been a considerable shift in FDI attraction in Georgia, but it should also be noted, that only technological novelties accompanying FDI are not sufficient to form a sustainable innovative sector. It requires innovative potential evaluation. Scientific elaboration and inventions should be brought to "market conditions". It also requires search for novelties and stimulation of demand for them, establishment of innovative firms, governmental support for their access to the foreign markets, and development of venture business. 
The government should permanently care for the development of fundamental and applied sciences in order to stimulate innovative activities. The private sector should take an active part in this process, too. Unfortunately, implementation of innovations and research and development in this direction is not a priority in Georgia. Despite this, our country should support the transition of branch institutions into the ownership of private companies and their business schemes and their activity should be focused on the market demand. National ideological importance should be attached to the innovative policy of the country. It must be acknowledged that innovations and information about them represent a means of confirmation of strategic prospects and rising capitalization. We should convince the consumers of intellectual services, that we have decent qualification and ability to work in this field. We should take into consideration the experience of China and India and use the technological culture of well-known foreign companies. We can also create our own methods of conducting highly technological business.

Legal regulation of intellectual property and copyright needs to be essentially changed to be in conformity with international standards. It requires development of research infrastructure and seize the opportunity opened by the world trend of transfer of high technology branches to the less developed countries because of their cheap labor. The revolutionary changes going on in the world economy make it clear that consumption of goods of the new economy and inclusion into the new innovative contours are simply impossible without knowledge. The countries out of the new innovative contours are doomed.

\section{Conclusion}

In summary, a two level system of factors defines the prospects of innovative development. The first level encompasses those strategies and methods which are applied by firms to reach and maintain competitiveness in the world market. At the second level, the government is a decisive factor, which provides direct or indirect support for local innovative firms.

Unfortunately, Georgia's export and economy structure, in which dominated agricultural products, raw materials (gold, copper), etc, makes draw two unfavorable conclusions: 1. Innovative activity of Georgian firms is low. That impedes reaching and maintaining international competitiveness; 2. The Georgian model of economic development does not correspond with that of developed countries. Georgia does not hold a single niche in the world market of innovative products. The government should permanently care for development of fundamental and applied sciences to stimulate innovative activities. The private sector should take an active part in this process, too. Legal regulation of intellectual property and copyright needs to be essentially changed to be in conformity with international standards.

\section{Bibliography}

[1] Daniels, J., Radenbaugh, L., Sullivan, D. (2013). International Business: Environments and Operations, 14th Ed. Pearson Prentice Hall.

[2] Doyle, P. (2002). Marketing Management and Strategy. Financial Times/Prentice Hall.

[3] Gogodze, I. (2010). Assessment and Monitoring of Innovative Processes in Europe. Tbilisi: http://www.inovdev.ge/uploads/files/51073S.Gogodze.pdf (seen 2017.03.01.).

[4] Innobarometer. (2015). The Innovation Trends at EU Enterprises . European Commission, http://ec.europa.eu/growth/industry/innovation/facts-figures/innobarometer/ (seen. 2017.02.12).

[5] Kim, W., Mauborgne, R. (2000). Knowing a Winning Business Idea When You See One. Harvard Business Review , https://hbr.org/2000/09/knowing-a-winning-business-idea-when-you-see-one (seen 2017.02.15).

[6] Meskhia, l., Shaburishvili, S. (2015). Basics of Researche of the Technological Environment of Business. Zeszyty Naukowe UNIWERSYTETU PRZYRODNICZO-HUMANISTYCZNEGO w SIEDLCACH, Seria: Administracja i Zarządzanie , 117-124.

[7] Meskhia, I., Shaburishvili, S. (2014). Major Threats to Economic Stability in the Post-communist Georgia: Reality and Prognosis. Organization in changing environment (pp. 31-44). Warsaw: Studio Emka.

[8] Shaburishvili, S. (2013). Peculiarities the commercialization of innovations. Innovation development of economy (pp. 173176). Minsk: GIUST BGU.

[9] Strovsky, L. (2007). Foreign economic activity of the enterprise. Moscow: UNITI.

[10] The Global Competitiveness Report. 2015-2016. Geneva: World Economic Forum. http://www3.weforum.org/docs/gcr/20152016/Global_Competitiveness_Report_2015-2016.pdf (2017.12.25).

[11] The Global Innovation Index 2015. Effective Innovation Policies for Development. Cornell University, INSEAD, and WIPO, $2015 \mathrm{http}: / / \mathrm{www}$. wipo.int/edocs/pubdocs/en/wipo_gii_2015.pdf (seen 2016.12.25).

[12] The Human Capital Report 2015. World Economic Forum. http://www3.weforum.org/docs/WEF_Human_Capital_Report_2015.pdf (seen 2016. 12. 25). 